\title{
Van 'n Eurosentriese na 'n Afrosentriese Geskiedenis - is daar ' $n$ alternatief?
}

\author{
P. de Klerk \\ Departement Geskiedenis \\ Vaaldriehoekkampus van die $\mathrm{PU}$ vir $\mathrm{CHO}$ \\ VANDERBIJLPARK
}

\begin{abstract}
A white-centred, or Eurocentric view of South African history has, until recently, been prevalent in textbooks and school syllabi. However, during the last two decades, a number of textbooks hove appeared which provide an Afrocentric view of South African history. This article examines to what extent it is possible to overcome both Eurocentrism and Afrocentrism in the interpretation of South African history and what the role of a Christian perspective on history can and should be in this regard. It is argued that the history of South Africa should be viewed within the context of the history of the world, and that any interpretation of world history involves a philosophy of history. A Christian view of history provides a unique perspective on the unity, history and on the role that different cultures and peoples play in the history of mankind. It is concluded that when a Christian view of history forms the basis of a scientific study of both world history and South African history, Eurocentric and Afrocentric interpretations can be avoided.
\end{abstract}

\section{Inleiding}

Die terme Eurosentrisme en Afrosentrisme word tans so baie in Suid-Afrika gebruik dat hulle clichés begin word. Ten opsigte van die Suid-Afrikaanse geskiedenis het hierdie terme tog ' $n$ besondere betekenis.

'n Blanksentriese of Eurosentriese siening van die Suid-Afrikaanse geskiedenis was tot onlangs aan die orde van die dag in Afrikaans- en Engelstalige oorsigwerke oor die Suid-Afrikaanse geskiedenis, asook in skool- en universiteitsillabusse. Die bekende Vyfhonderd jaar Suid-Afrikaanse geskiedenis (Muller, 1980), wat tans nog as handboek aan sommige Afrikaanse universiteite gebruik word, behandel byvoorbeeld, "die doen en late van die witman in Suid-Afrika oor bykans ' $n$ halfmillennium" (Muller, 1980: ix) en begin by die ontdekking van die seeroete na Indië deur die Portugese. Die geskiedenis van die land voor die koms van die blankes word heeltemal buite rekening gelaat. Die klem val dus steeds op 
die blankes, Afrikaans- en Engelssprekend, en op die Westerse kultuur in SuidAfrika. Teen die einde van die sestigerjare het die eerste gesaghebbende oorsigwerk oor die Suid-Afrikaanse geskiedenis verskyn waarin die Suid-Afrikaanse geskiedenis vanuit ' $\mathrm{n}$ heeltemal ander perspektief bekyk word. In The Oxford History of South Africa (Wilson \& Thompson, 1969-1971) word meer as 'n derde van die eerste boekdeel gewy aan die voor-koloniale tydperk, en in albei boekdele staan die geskiedenis van die swart mense, diegene wat reeds voor die koms van die blankes in die land gewoon het, in die sentrum. Die blankes word aangedui as die setlaars wat die land steeds verder binnegedring het - ' $n$ tendens wat voortdurend deur die swart mense teengestaan is. Hierdie nuwe benadering tot die Suid-Afrikaanse geskiedenis het veral na vore gekom as gevolg van die ontwaking van die belangstelling in Afrikageskiedenis gedurende die sestigerjare. Onder historici in die VSA, Europa en ook Suid-Afrika (veral aan die Engelstalige universiteite) is die geskiedenis van Suid-Afrika steeds meer in die lig van die geskiedenis van Afrika beskou, en sodoende het 'n Afrosentriese perspektief op die Suid-Afrikaanse geskiedenis inslag begin vind.

Suid-Afrika is, wat hierdie twee botsende perspektiewe op sy geskiedenis betref, in 'n besondere posisie. Die geskiedenis van die VSA en Australië word byvoorbeeld steeds hoofsaaklik vanuit ' $n$ Westerse perspektief behandel. Die ontwikkeling van 'n Westerse samelewing in hierdie lande, en nie die lotgevalle van die Indiane of die Australiese inboorlinge nie, staan in oorsigwerke oor die twee lande in die sentrum. In werke wat in die afgelope dekades oor byvoorbeeld die geskiedenis van Indië verskyn het (bv. Thapar \& Spear, 1965-1966; Kulke \& Rothermund, 1986), is dit weer die inheemse bevolking, die Indiërs, waarop hoofsaaklik gefokus word, en nie die blanke maghebbers nie - maghebbers wie se tyd van oorheersing duidelik reeds verby is. Terwyl die kolonisasie van die VSA en Australië gelei het tot die totstandkoming van Westerse samelewings in dié lande, was Westerse kolonisasie in Indië en in die grootste deel van Afrika net ' $n$ verbygaande fase. Suid-Afrika beklee in hierdie opsig 'n tussenposisie (vgl. Fisch, 1990:i). Toekomstige ontwikkelinge in Suid-Afrika mag daartoe lei dat oor vyftig of honderd jaar die tydperk van Westerse oorheersing en van 'n Westers gedomineerde samelewing as 'n fase wat verbygegaan het, gesien sal word. Dit kan egter verwag word dat in die huidige tydsgewrig die twee kardinaal verskillende perspektiewe naas mekaar sal bly bestaan.

Die ingrypende politieke veranderinge in Suid-Afrika wat tans voor die deur staan, sal ongetwyfeld ook in die geskiedenisonderwys, op skool en op universiteit, 'n neerslag vind. Hierby moet in gedagte gehou word dat Geskiedenissillabusse in Suid-Afrika, soos in baie ander lande, veral op skoolvlak tot ' $n$ groot mate as ' $n$ heerskappy-instrument gebruik is. "Regering na regering het sy geskiedenisbeeld op ander groepe afgedwing" (Van Jaarsveld, 1989:19). Oor die invloed wat sentrale en streeksowerhede in 'n nuwe bedeling op die inhoud van 
skool- en universiteitsillabusse kan hê, kan tans net gespekuleer word. Dit kan tog van waarde wees as vooraf prinsipieel besin word oor hoe sulke sillabusse daar behoort uit te sien, en met hierdie artikel word gepoog om, ten opsigte van enkele aspekte, tot so ' $n$ besinning by te dra. In besonder sal gepoog word om die vraag te beantwoord in hoeverre dit moontlik is om sowel ' $n$ Eurosentriese as ' $n$ Afrosentriese interpretasie van die Suid-Afrikaanse geskiedenis te vermy en in watter opsigte 'n Christelike geskiedbeskouing ' $n$ antwoord op hierdie probleem kan bied.1

\section{Die Suid-Afrikaanse geskiedenis as deel van 'n groter geheel}

Is dit hoegenaamd moontlik om Eurosentrisme of Afrosentrisme in die vorming van 'n geheelbeeld van die Suid-Afrikaanse geskiedenis te vermy? Is die ideaal van skoolsillabusse wat "nóg blanksentries nóg swartsentries ... maar histories ewewigtig, getrou en verantwoord" is (Kapp, 1992:8), bereikbaar? Pogings om 'n middeweg tussen 'n Eurosentriese en 'n Afrosentriese uitkyk te volg in oorsigwerke soos dié van Van Aswegen (1989) en Davenport (1991), het daartoe gelei dat daar nie 'n duidelike eenheidsvisie op die geskiedenis gebied word nie. Van Aswegen, wat net die geskiedenis tot 1854 behandel, het sy werk in 'n groot aantal afdelings en onderafdelings ingedeel, waardeur die geheelsamehang nie goed na vore kom nie (vgl. Liebenberg, 1990). Davenport se gedeeltelik tematiese indeling, sy taamlik gedetailleerde beskrywing van gebeure en sy bespreking van verskillende sieninge oor bepaalde sake (vgl. Garson, 1992:55; Le Cordeur, 1992:40-41; Legassick, 1992:44-45; Smith, 1992:50), bring mee dat ook hy nie 'n duidelike eenheidsbeeld bied nie. Historici het sy werk bowendien nog steeds bestempel as ' $n$ "white, middle-class, elitist view of South African history" (Le Cordeur, 1992:41; Smith, 1992:51)

Gaan die historikus se kultuuragtergrond, wat in die geval van byvoorbeeld ' $n$ blanke skrywer deurgaans sterk Westers sal wees, maar in die geval van 'n swart historikus moontlik heelwat elemente van 'n inheemse Afrikakultuur sal bevat, nie in elk geval 'n deurslaggewende rol in sy perspektief op die geskiedenis speel nie? Dit moet in gedagte gehou word dat die meeste historici wat 'n Afrosentriese beeld van die Suid-Afrikaanse geskiedenis probeer bied self Westerlinge is. Dit bly ' $n$ historikus se taak om vroeëre tydperke en kulture te verstaan deur hom in

1 Dic problecm van Eurosentrisme en Afrosentrisme in die Suid-Afrikaanse historiografie hou verband met ander vraagstukke, soos dic plck wat politicke en sosiale geskicdenis, onderskcidelik, in dic geskicdskrywing behoort te beklec en hoevecl aandag aan dic optrede van leidende figure, aan die een kant, en aan dic lecfwyse van die gewone mense, aan die ander kant. gegec behoort te word. Hierdie sake, waaroor daar verskillende standpunte onder historici bestaan en waaroor daar reeds talle publikasies verskyn het, word in die artikel buite beskouing gelaat 
die besondere aard van elke tydvak te probeer inleef, maar hy sal hom tog nie van sy eie Westerse kultuuragtergrond kan losmaak nie. Dit word nog ingewikkelder as in gedagte gehou word dat die geskiedeniswetenskap in die Westerse wêreld ontwikkel het en daarom eintlik self deel van die Westerse kultuur vorm. Ook 'n historikus met 'n Afrika-kultuuragtergrond kan nie aan hierdie Westerse kultuurinvloed ontkom nie, en dis onwaarskynlik dat Eurosentrisme in die sin van Westerse terme soos Nuwe Wêreld sal verdwyn, soos E. Messina (1991) byvoorbeeld wil hê (vgl. ook Wheatcroft, 1992). Afrosentrisme as 'n siening van SuidAfrikaanse geskiedenis kan dus nie beteken dat die invloed van die Westerse kultuur uitgeskakel word nie. Dit beteken slegs dat die rol van die swart mense in die Suid-Afrikaanse geskiedenis in die sentrum staan en die geskiedenis veral binne die groter geheel van die geskiedenis van Afrika gesien en geïnterpreteer word.

Die opmerkings in die paragraaf hierbo toon dat die probleem van Euro- en Afrosentrisme veral te make het met die aard van die groter geheel waarbinne die Suid-Afrikaanse geskiedenis gesien word. Die geskiedenis van Suid-Afrika vorm, net so min as dié van enige ander land, volk of beskawing, 'n afgeslote geheel, maar is in alle opsigte met die geskiedenis van ander lande, en derhalwe met die geskiedenis van sowel Afrika as Europa, en uiteindelik met die hele wêreldgeskiedenis, vervleg. Die agtergrond waarteen die Suid-Afrikaanse geskiedenis gesien word, gaan uiteindelik die perspektief wat daarop verkry word, bepaal.

Ongelukkig kom hierdie vervlegtheid met 'n groter geheel feitlik nie in skool- en universiteitsillabusse en ook nie in oorsigwerke oor die Suid-Afrikaanse geskiedenis na vore nie, en sodoende kan die geskiedenis nie binne 'n breër konteks gesien en 'n wyer perspektief daarop gevorm word nie. Dit is nie net 'n probleem wat in Suid-Afrika bestaan nie:

The dilemma is obvious, visible in most history texts and in all but the most experimental curricula: the past is divided in two parts, the United States and whatever else in the world is studied historically or, more simply and obviously, US and THEM (Stearns, 1989:12).

In sowel sogenaamde Eurosentriese as sogenaamde Afrosentriese sintesewerke word die konteks waarin die Suid-Afrikaanse geskiedenis bekyk moet word, verwaarloos. In die eerste hoofstuk van Vyfhonderd jaar Suid-Afrikaanse geskiedenis (Muller, 1980) word die verloop van die Portugese ontdekkingstogte langs die weskus van Afrika en die uiteindelike reis om die Kaap redelik uitgebreid behandel, maar daar word net baie kortliks verwys na gebeure in Nederland en na die ontwikkeling van die Nederlandse handelsryk in die Ooste. In die hele gedeelte oor die Kompanjiestydperk is daar net baie kort verwysings na die ontwikkelinge in Nederland en na, onder meer, die redes vir die agteruitgang van die Kompanjie, die Europese agtergrond vir die ontstaan van die Patriotbeweging en 
die redes vir die Britse oorname van die Kaap in 1806. As nie goed verduidelik word waarom die Nederlandse bewind met 'n Britse bewind vervang is nie, kan die oorsake van een van die mees ingrypende wendinge in die Suid-Afrikaanse geskiedenis nie begryp word nie. Ook wat die Britse tydperk betref, is die verwysings na ontwikkelinge in Brittanje en Europa baie beknop, en die agtergrond tot die oplewing van Britse imperialisme in die laat negentiende eeu word byna nie behandel nie. Die redes vir die uitbreek van die twee wêreldoorloë, die oorsake vir die verandering van die Britse Ryk in ' $n$ Statebond en die agtergrond tot die dekolonisasie van Afrika word ook feitlik nie bespreek nie (vgl. Bergh, 1987:18). The Oxford History of South Africa (Wilson \& Thompson, 1969-1971) toon soortgelyke leemtes. Hoewel daar hoofstukke is oor die argeologiese agtergrond tot die Suid-Afrikaanse geskiedenis en oor die leefwyse en samelewingstruktuur van die Khoisan, die Nguni, die Sotho en die Venda, word daar weinig of geen verbande getrek met die ontwikkelinge in ander dele van Afrika nie. Sodoende kan nie bepaal word in hoeverre die kulture van die inwoners van SuidAfrika unieke kenmerke gehad het en in hoeverre hierdie kulture deel was van 'n patroon wat in groter dele van Afrika gegeld het nie. Selfs die laaste hoofstuk van die werk, oor Suid-Afrika en die moderne wêreld, handel hoofsaaklik oor Suid-Afrika se buitelandse beleid, feitlik sonder om die veranderinge wat daar op die wêreldtoneel in die algemeen plaasgevind het te verduidelik

Ook in resente sintesewerke, soos dié van Van Aswegen (1989), Fisch (1990), Thompson (1990) en Davenport (1991), word weinig aandag gegee aan die agtergrond waarteen die ontwikkelinge in Suid-Afrika gesien moet word. Hoewel Davenport die geskiedenis van swart nasionalistiese bewegings deeglik behandel, dui hy feitlik nie die verband met dekolonisasie en nasionalisme in die res van Afrika aan nie. Ook in sy hoofstuk oor die ekonomiese ontwikkeling van die land in die twintigste eeu, word nie aangetoon hoe dit beïnvloed is deur en saamhang met die ekonomiese ontwikkeling van die Westerse wêreld nie.

Daar het wel enkele oorsigwerke verskyn waarin die wyer konteks waarbinne die Suid-Afrikaanse geskiedenis gesien moet word, beter tot sy reg kom. F.A. van Jaarsveld begin sy Van Van Riebeeck tot P.W. Botha (1982) met 'n afdeling waarin die geskiedenis van Suid-Afrika kortliks teen die agtergrond van die opkoms en verswakking van die Europese heerskappy oor die wêreld geplaas word waarna hy die strategiese belangrikheid van Suid-Afrika en die invloed daarvan op sy geskiedenis kortliks bespreek. In 'n hoofstuk oor die herkoms en verspreiding van die swart mense in Suid-Afrika word na die verband met volke in ander dele van Afrika verwys, hoewel verouderde gegewens gebruik word. Die boek bevat ook ' $n$ hoofstuk waarin die Westerse kolonisasie en dekolonisasie van Afrika behandel en die posisie van Suid-Afrika binne hierdie wyer konteks aangedui word. Die trek van groter verbande word ongelukkig net tot enkele hoofstukke beperk, en daar word, byvoorbeeld, nie veel aandag gegee aan sewentiende en 
Van 'n Eurosentriese na 'n Afrosentriese Geskiedenis is daar 'n alternatief?

agtiende-eeuse ontwikkelinge in Europa wat Suid-Afrika beïnloed het nie. Van Jaarsveld beweeg in ' $n$ belangrike mate weg van die blanksentriese benadering van Muller, maar plaas tog die Suid-Afrikaanse geskiedenis grotendeels net binne die konteks van die Westerse geskiedenis.

The Shaping of South African Society, 1652-1840 (Elphick \& Giliomee, 1989) bevat twee hoofstukke waarin heelwat aandag aan die wyer konteks gegee word. Veral die hoofstuk oor die Kaapkolonie en die wêreldekonomie in die periode 1652-1835 (Ross, 1989) bied belangrike perspektiewe wat nie in ander oorsigwerke na vore kom nie. Die Nederlandse Oos-Indiese Kompanjie (VOC) se ekonomiese stelsel word goed verduidelik, en daar word aangetoon hoe die wêreldekonomie die samelewing aan die Kaap beïnvloed het, hoewel Ross se siening van die wêreldekonomie as sisteem aanvegbaar is. Die hoofstuk oor die VOC en die Kaapse koloniste (Schutte, 1989) bevat ook inligting oor die algemene struktuur van die Kompanjie. Ongelukkig word nie in een van die twee hoofstukke goed aangedui hoe omstandighede en ontwikkelinge in Oos-Asië die samelewing aan die Kaap beïnloed het nie. In die hoofstukke waarin die slawebevolking behandel word, word ook nie veel meegedeel van die Oosterse kultuur en leefwyse wat baie van die slawe gehad het en die invloed daarvan op die Kaapse samelewing nie. Daar word baie aandag gegee aan die inheemse bevolking, wat voor 1652 in die gebied van die latere Kaapkolonie geleef het, en aan die wyse waarop hul samelewing na die koms van die blankes verander het. Ook in hierdie werk word die kultuur en leefwyse van dié groepe nie binne die breër konteks van ontwikkelinge in Afrika geplaas nie.

Stearns (1989) pleit vir sillabusse en handboeke waarin die Amerikaanse geskiedenis met die Westerse geskiedenis geïntegreer word, omdat, soos hy tereg aandui, die ontwikkeling van die VSA hoofsaaklik gesien kan word as 'n uitbreiding van die Westerse beskawing. Wat Suid-Afrika betref, is die saak nie so eenvoudig nie en behoort die Suid-Afrikaanse geskiedenis, soos uit die kort bespreking van enkele oorsigwerke na vore kom, met sowel die geskiedenis van Afrika as dié van die Weste geïntegreer te word, terwyl ook die verband met ontwikkelinge in die Ooste, veral gedurende die Nederlandse en Britse koloniale tydperke, belangrik is. Die Suid-Afrikaanse geskiedenis moet binne die konteks van die hele wêreldgeskiedenis behandel word, en die beeld van die wêreldgeskiedenis waarbinne die geskiedenis van Suid-Afrika beskou word, sal die beeld wat van die Suid-Afrikaanse geskiedenis gevorm word, bepaal. 


\section{Probleme insake die vorming van 'n geheelbeeld van die wêreldgeskiedenis}

Die beoefening van wêreldgeskiedenis en die vorming van ' $n$ geheelbeeld van die wêreldgeskiedenis geniet tans baie aandag onder historici. Akademici wat hul met die studie van wêreldgeskiedenis besig hou, het verskillende uitgangspunte en verskillende perspektiewe op die wêreldgeskiedenis. Daarom moet kortliks ingegaan word op enkele probleme insake die vorming van 'n beeld van die wêreldgeskiedenis.

Die besef dat die geskiedenis van alle mense en volke op aarde een samehangende geheel vorm, is 'n kernelement van 'n Christelike perspektief op die geskiedenis en het juis as gevolg van die opkoms van die Christendom 'n algemeen aanvaarde beskouing geword (vgl. Collingwood, 1946:46; Smit, 1950:106; Den Boer et al., 1960:75). In die Oudheid, en by die volke van Asië en Afrika ook nog eeue lank daarna, is die geskiedenis nie as 'n eenheid gesien nie. Die mense van die Oudheid se kennis en begrip van die geskiedenis was sterk verweef met hul belewing van die natuur. Hulle het hul eie lewens gesien as oorskadu deur 'n ewige en onveranderlike natuur met ' $n$ steeds terugkerende kringloop, en 'n sikliese tydsbegrip het by hulle voorgekom (Van der Walt, 1978:33-34; Bebbington, 1979:21; Van der Dussen, 1986:29). Hierdie tydsbegrip is ook nog aanwesig in Oosterse godsdienste en beskouinge van ons eie tyd, soos in die Hindoeïsme en Boeddhisme (Cairns, 1963:35-68; Bebbington, 1979:21-28).

Hoewel die vroeg-Christelike en Middeleeuse skrywers 'n besef van die wêreldgeskiedenis as ' $n$ eenheid gehad het, was hulle kennis van hierdie geskiedenis tog baie beperk. Hulle het byvoorbeeld feitlik geen kennis van die volke van Sentraal- en Oos-Asië gehad nie en het hoofsaaklik geskryf oor die vroeë Nabye Ooste en die Grieks-Romeinse wêreld en verder oor latere ontwikkelinge in hul eie lande. Die ontdekkingsreise van die vyftiende en sestiende eeue het groter kennis van die wêreld en die wêreldgeskiedenis gebring, en in die agtiende eeu is heelwat aandag aan die geskiedenis van die Oosterse volke gegee (vgl. De Klerk, 1992:7-8). In die negentiende eeu, toe die geskiedkunde as 'n wetenskaplike dissipline sy beslag gekry het, het die meeste skrywers tog slegs belanggestel in die geskiedenis van hul eie land en volk. Leopold von Ranke, wat as die vader van die wetenskaplike geskiedenis beskou kan word, het wel 'n wêreldgeskiedenis probeer skryf, maar dit handel feitlik net oor die geskiedenis van die Midde-Ooste en Europa (vgl. Den Boer et al., 1960:198; Vogt, 1961:18; Van Jaarsveld, 1980:14). Vir die meeste historici van daardie tyd was wêreldgeskiedenis feitlik sinoniem met die geskiedenis van die Weste. Daar is geglo dat geskiedenis eintlik net op grond van geskrewe bronne geskryf kan word en dat veral die sogenaamde skriflose samelewings, soos die volke van Afrika suid van die 
Sahara, 'n statiese kultuur en daarom eintlik geen geskiedenis het nie, terwyl die Indiese en Chinese beskawings buite die hoofstroom van die geskiedenis staan (vgl. Den Boer et al., 1960:198; Harmsen, 1968:72).

In die twintigste eeu het die behoefte om die wêreldgeskiedenis werklik in sy geheel te ken en te beskryf dringender geword. Feitlik geen volk of samelewing het nou meer in isolasie geleef nie en gebeure in een deel van die wêreld het gebeure in 'n ander deel al meer direk geraak. Nuwe kennis oor die vroeë geskiedenis van Asië, Afrika en Amerika, onder meer deur steeds verdere argeologiese studie, het getoon dat daar veel meer kontak tussen die ou beskawings was as wat vroeër bekend was en dat die gedagte dat daar voor die moderne tyd nie van 'n wêreldgeskiedenis sprake kan wees nie, nie houdbaar is nie. Resente paleontologiese, antropologiese en taalkundige navorsing dui ook op 'n gemeenskaplike ontstaansgeskiedenis van die mensheid. Historici het al meer tot die besef gekom dat op grond van nie-skriftelike bronne ook heelwat historiese kennis gevorm kan word en die beskouing dat daar 'geskiedenislose' volke is, is laat vaar. Verder het daar, veral na die beëindiging van Europese koloniale beheer in Asië en Afrika, in die Weste ' $\mathrm{n}$ al hoe groter belangstelling in die geskiedenis van hierdie wêrelddele ontstaan.

Die strewe om van 'n Eurosentriese uitkyk weg te beweeg, kom veral na vore in 'n projek wat in die vyftigerjare deur Unesco (United Nations Educational, Scientific and Cultural Organization) onderneem is om 'n versamelwerk, getiteld History of Mankind: Cultural and Scientific Development (Unesco, 1963-1966), tot stand te bring. Skrywers van hierdie reeks het gepoog om ewe veel ruimte aan die bydrae van elke kultuur te gee, en na die verskyning van die werk het sommige kritici verklaar dat so 'n geskiedwerk waarin alle volke en samelewings gelyke behandeling ontvang, uiteindelik geen geheelbeeld van die wêreldgeskiedenis bied nie (Allardyce, 1990:35-37; vgl. ook Ledbetter, 1992). Die tendens om aan alle kulture ewe veel aandag te probeer gee, is nog verder gevoer in die VSA met sogenaamde multikulturele skoolleerplanne waarin baie aandag aan die geskiedenis van nie-Westerse kulture gegee word, maar soms so ver gegaan word om van aanvaarde wetenskaplike interpretasies van die geskiedenis af te wyk. Dit is onder meer die geval met die handboeke van die Afrosentriese Onderwysbeweging, waarin beweer word dat die ou Egiptenare swart mense was, dat die Grieke talle dinge van hulle oorgeneem het en dat die Westerse wetenskap, filosofie en godsdiens sy oorsprong dus in hierdie beskawing van swart mense het (vgl. Singer, 1990; Ravitch, 1991; Martel, 1991-1992; Levine, 1992). Aan die strewe van die Afrosentriese Onderwysbeweging is verdere stukrag verleen deur die teorie van die Egiptiese skrywer $\mathrm{S}$. Amin dat Eurosentrisme ' $\mathrm{n}$ mite is wat, onder meer, 'n verdraaiing van die wêreldgeskiedenis behels en wat vanaf die 
sestiende eeu met die opkoms van die kapitalistiese wêreldsisteem onstaan het (Amin, 1989) ${ }^{2}$.

In die afgelope jare is aan ' $n$ hele aantal Amerikaanse universiteite en kolleges inleidende kursusse in wêreldgeskiedenis ingestel en is verskeie handboeke wat 'n oorsig van die wêreldgeskiedenis gee, geskryf. Die werke van McNeill (1963) en Stavrianos (1971) was veral invloedryk en het as model gedien vir verskeie handboeke wat later verskyn het. Hierdie boeke het dikwels tog die kritiek ontlok dat hulle nog ' $n$ te Westerssentriese karakter het (vgl. Allardyce, 1990; Hitchens, 1990; McNeill, 1990; Green, 1992:41; Manning, 1992).

Die feit dat dit so moeilik was vir historici om 'n wetenskaplike werk tot stand te bring wat 'n duidelike geheelbeeld van die wêreldgeskiedenis bied, het waarskynlik belangstelling in teoretiese raamwerke waarin die wêreldgeskiedenis omvat kan word, bevorder. Die historikus Amold Toynbee se sisteem van beskawings, soos uiteengesit in sy twaalfdelige A Study of History (1935-1961), het wye belangstelling gewek, maar ook skerp kritiek van historici uitgelok. Immanuel Wallerstein se The Modern World System (1974-1989) het groter aanklank by historici gevind, waarskynlik veral omdat dit aansluit by die Marxistiese ekonomiese teorie wat deur baie Westerse historici aanvaar is. Wallerstein het, streng gesproke, 'n Westerssentriese siening van die wêreldgeskiedenis, maar sy teorie dat ' $n$ Westerse kapitalistiese wêreldekonomie vanaf die sestiende eeu tot stand gekom het waarin die nie-Westerse wêreld die randgebied van die Weste geword en deur die Weste ekonomies uitgebuit is, is juis verwelkom deur historici wat spesialiseer in die geskiedenis van Asië en Afrika (Green, 1992:47; vgl. ook Amin, 1989). Die gebruik van sulke teoretiese modelle druis tog in teen die metodologie en werkwyse wat die meeste historici vandag nog oor die algemeen volg. ' $n$ Onvattende teorie waarin beskawings of ekonomiese sisteme as basiese eenhede van die wêreldgeskiedenis gesien word, maak dit net moontlik om bepaalde verbande wat binne en tussen hierdie eenhede bestaan, raak te sien, maar nie geskiedskrywing waarin alle samehange behandel en die wêreldgeskiedenis as een samehangende geheel beskryf word nie. Aan die ander kant is bepaalde uitgangspunte oor die aard van die geskiedenis en die wêreldgeskiedenis tog nodig ten einde dit moontlik te maak om die verskillende beskawings en kulture op ' $n$ sinvolle wyse in ' $n$ geheelbeeld te integreer en nie net volgens eie voorkeure aan sekere beskawings meer en aan ander beskawings minder aandag te gee of aan elke kultuur 'ewe veel plek' toe te ken, soos in die Unesco-projek, nie.

2. Amin (1989:vii) gec sy eic besonderc inhoud aan dic term Eurosentrisme: "Eurocentrism is a culturalist phenomenon in the sense that it assumes the existence of irreducibly distinct cultural invariants that shape the historical paths of different peoples. Eurocentrism is therefore anti-universalist, for it claims that imitation of the Western model by all pooples is the only solution to the challenges of our time." 
Die World History Association, gestig in 1982, beywer hom veral daarvoor dat 'n beeld van die wêreldgeskiedenis posvat waarin Europa en die Weste nie noodwendig in die sentrum staan nie, maar lede van die organisasie het tot die besef gekom dat ' $n$ duidelike geheelbeeld van die wêreldgeskiedenis nie sonder 'n grondliggende idee of geskiedbeskouing verkry kan word nie. "'What the organization needs', a member remarked, is 'a simple, all-encompassing, elegant idea with the power to order human experience'" (Allardyce, 1990:67.)

\section{Aspekte van 'n Christelike beskouing van die wêreld- geskiedenis}

'n Grondliggende beskouing oor die aard van die geskiedenis is dus nodig om 'n geheelperspektief op die wêreldgeskiedenis te kan vorm. Alhoewel Christelike denkers, ook Calvinisties-Christelike denkers, geensins in alle opsigte saamstem oor die kenmerke van 'n Christelike geskiedbeskouing nie (vgl. McIntire, 1977; Van der Merwe, 1967), is daar tog bepaalde Bybelse gesigspunte wat kernelemente van alle Christelike beskouinge van die geskiedenis vorm (vgl. De Klerk, 1988:16-20). Enkele belangrike gesigspunte is dat uit God, deur God en tot God alle dinge is (Romeine 11) en dat die wêreldgeskiedenis daarom ten diepste betrokke is op God. Voortvloeiend hieruit is die gesigspunt dat God alles, ook die eerste mense, geskape het en dat die skepping die beginpunt van die wêreldgeskiedenis vorm. Die mens het 'n besondere plek in Gods skepping en het die opdrag om die aarde te vul en te vermeerder en te heers oor die dierewêreld (Genesis 1). God is nie net Skepper nie, maar ook Heerser oor die skepping. Gods Hand is daarom oral in die geskiedenis aanwesig. (Vgl. hieroor verder Smit, 1987.) Die Bybel leer dat God alles goed geskape het, maar dat die hele skepping deur die sonde aangetas is as gevolg van die ongehoorsaamheid van die mens. Hierdeur is die besondere band tussen God en mens verbreek, maar deur sy menswording, kruisdood en opstanding het Christus, die Seun van God, vir die mensheid se sondeskuld betaal en die band tussen God en mens herstel. Die Bybel leer ons verder dat daar met die wederkoms van Christus 'n einde aan hierdie aardse bedeling en daannee aan die wêreldgeskiedenis sal kom.

In filosofiese strominge wat 'n belangrike invloed op die geskiedkunde gehad het, onder meer in die Marxistiese denke, was 'n Westerssentriese siening van die wêreldgeskiedenis dikwels ingebou. Kan in 'n Christelike geskiedbeskouing 'n Westerssentriese siening van die wêreldgeskiedenis oorkom word? Soos in die vorige afdeling aangetoon, het die Christelike beskouing van die wêreldgeskiedenis eers vanaf die Middeleeue met 'n Westerssentriese siening verweef geraak. Ook by twee grondleggers van die moderne Calvinistiese denke, Abraham Kuyper en Herman Dooyeweerd, word wêreldgeskiedenis en Westerse geskiedenis byna aan mekaar gelykgestel. Kuyper meen dat die volke van Asië en Afrika maar min tot die ontwikkeling van die mensheid bygedra het en verwys in 1898 na die leefwyse van die inwoners van Afrika as "een nog veel lager levens- 
vorm" as dié van die mense van Asië (Kuyper, 1959:25). Dooyeweerd sien die inheemse kulture van Afrika as staties van aard; slegs deur kontak met ander groepe wat reeds op 'n hoër vlak van ontwikkeling is, kan die gemeenskappe opgeneem word in die hoofstroom van beskawingsontwikkeling (Dooyeweerd, 1955:665), en hierdie hoofstroom is duidelik hoofsaaklik die Westerse geskiedenis. Kuyper en Dooyeweerd reflekteer die opvattinge van hul tyd, waaronder ook die algemene geloof onder die Europeërs van die laat negentiende en vroeë twintigste eeue dat die Westerse beskawing van hul tyd 'n veel hoër vlak as ander kulture bereik het en dat die uitbreiding van Westerse gesag en van die Westerse kultuur oor Afrika en Asië tot die vooruitgang van hierdie wêrelddele, in besonder, en van die mensheid in die algemeen, moet lei (vgl. De Klerk, 1989 252-253)

'n Bybelse perspektief op die geskiedenis, soos hierbo kortliks saamgevat is, impliseer tog geensins 'n Eurosentriese beskouing nie. Wes-Europa, Amerika en die grootste dele van Afrika en Asië lê buitendien almal buite die verwysingsveld van die Bybel. Dit is veral die Bybelse beskouing dat die mensheid ' $n$ eenheid is en vanaf een punt oor die aarde versprei het, en dat die wêreldgeskiedenis dit is wat met die mensheid vanaf die skepping tot aan die voleinding gebeur en wat uiteindelik deur 'n Goddelike Raadsplan bepaal word, wat gelei het tot die groot omwenteling in die geskiedbeskouing in die vroeg-Christelike tyd (vgl. Collingwood, 1946:46; Smit, 1950:106; McIntire, 1975:55). Eers in die loop van eeue het Westerse Christene se beeld van die geskiedenis verder vorm aangeneem en het die ontwikkeling van die Westerse beskawing daarin ' $n$ sentrale plek gekry. Aanvanklik het die Christendom veral in Wes-Asië en Noord-Afrika versprei en daar die algemene godsdiens geword. Die Christendom het daarna 'n besondere rol in die ontwikkeling van die Westerse beskawing gespeel, maar, terwyl die Weste al meer gesekulariseerd geraak het, het die Christendom in die negentiende en twintigste eeue sterk in Afrika en ook in Asië begin posvat. Latyns-Amerika, wat sedert die koms van die Portugese en Spanjaarde gekersten is, word vandag nie meer as 'n deel van die hoog ontwikkelde Westerse lande gereken nie, maar eerder as ' $n$ deel van die Derde Wêreld. Die Christendom het veral 'n godsdiens van die Derde Wêreld geword, en 'n Christelike perspektief op die wêreldgeskiedenis kan vandag sekerlik nie meer sinoniem met ' $n$ Westerse perspektief wees nie.

'n Christelike beskouing van die geskiedenis is nie 'n omvattende teoretiese sisteem wat vooraf aanvaar word en waarbinne die wêreldgeskiedenis georden moet word, soos dié van Marx, nie. 'n Christelike geskiedsbeskouing bevat slegs enkele basiese opvattinge oor die begin, verloop en einde van die wêreldgeskiedenis wat as uitgangspunte en riglyne vir die historikus dien. Historici moet deur die wetenskaplike ondersoek van alle beskikbare bronne kennis van die geskiedenis bekom en kan dan eers, deur 'n sintese van hierdie kennis, ' $n$ geheelbeeld van die 
geskiedenis vorm. Wanneer 'n wetenskaplike werk oor die wêreldgeskiedenis vanuit ' $n$ Christelike perspektief gelewer word, impliseer dit ook nie dat die koms van Christus en die geskiedenis van die Christendom in die sentrum daarvan moet staan nie. Smit (1950:117-118) wys daarop dat enige pogings om die koms van Christus 'n sentrale plek in die periodisering van die wêreldgeskiedenis toe te ken te staan kom voor die probleem dat die Christendom eers etlike eeue later 'n belangrike rol in die wêreldgeskiedenis begin speel het. Hoewel in die geloof die koms van Christus as kardinale keerpunt in die geskiedenis gesien word, stuit 'n mens voor onomstootlike probleme om dit in die geskiedskrywing aan te toon (Klapwijk, 1974:67; Smit, 1950:118). Wanneer van Christus as sentrum van die geskiedenis gepraat word, word daarmee gewoonlik bedoel 'n singewende sentrum (vgl. Dreyer, 1974:220; Smit, 1987: 20). Deur die versoeningsdood van Christus word die sin van die skepping herstel, en daarmee ook die sin van die wêreldgeskiedenis. In 'n Christelike lewens- en wêreldbeskouing, en daarmee ook in 'n Christelike geskiedbeskouing, staan Christus sentraal en beïnvloed so ook 'n Christelike historikus se beeld van die wêreldgeskiedenis (vgl. ook De Klerk, 1988:107, 112). Die rol van die Christendom in die verloop van die wêreldgeskiedenis behoort in 'n werk vanuit 'n Christelike perspektief vanselfsprekend tot sy volle reg te kom, maar dit kan, byvoorbeeld, nie beteken dat die rol van die Islam en sy kultuurprestasies gedurende die vroeë Middeleeue of die misdade wat in die loop van die geskiedenis in die naam van die Christendom gepleeg is, geïgnoreer word nie.

Enige geheelinterpretasie van die wêreldgeskiedenis bevat altyd 'n element van voorlopigheid. Historici se kennis van die mensheid se vroeë geskiedenis is baie onvolledig, maar neem as gevolg van argeologiese en ander navorsing steeds toe. Verder beïnvloed nuwe ontwikkelinge steeds die interpretasie van vroeëre gebeure. Die omwentelinge in Oos-Europa in die afgelope paar jaar het byvoorbeeld die geskiedenis van die Kommunisme in 'n heeltemal nuwe perspektief geplaas. Om ' $n$ beeld van die wêreldgeskiedenis, en van die Suid-Afrikaanse geskiedenis te vorm, ook vanuit 'n Christelike oogpunt, is dus 'n proses wat steeds voortgaan. 'n Christelike beskouing van die wêreldgeskiedenis bied verder nie 'n antwoord op alle probleme aangaande die vorming van 'n geheelbeeld van die geskiedenis nie, maar die Christelike siening van die eenheid van die geskiedenis maak dit tog moontlik om die plek van die dele binne die groter geheel duideliker te sien.

Daar is, sover ek weet, in die afgelope paar dekades geen poging aangewend om spesifiek vanuit 'n Christelike oogpunt 'n omvattende geheelbeeld van die wêreldgeskiedenis, gegrond op resente navorsing, te vorm nie. As so 'n werk tot stand sou kom, kan dit van groot waarde wees, maar intussen bly dit steeds moontlik om krities van bestaande sintesewerke gebruik te maak om vanuit 'n Christelike oogpunt 'n geheelperspektief op die wêreldgeskiedenis te verkry. Om 'n antwoord te vind op vrae soos watter plek die geskiedenis van Afrika en van Europa, 
of van die Westerse beskawing, in 'n Christelike beskouing van die wêreldgeskiedenis behoort in te neem, sal sulke werke nader bekyk moet word. 'n Uitgebreide bespreking is nie binne die bestek van hierdie artikel moontlik nie, en daarom word met ' $n$ enkele opmerking oor die plek van Afrika en Europa in die wêreldgeskiedenis volstaan.

Indien aanvaar word dat die wêreldgeskiedenis gesien kan word as die ontwikkeling van die menslike samelewing en kultuur in sy totaliteit, en vanaf die vroegste tye tot vandag toe (vgl. McIntire, 1984; De Klerk, 1988), dan impliseer dit dat die plek van 'n volk, kultuur of beskawing binne die geheelsamehang van die mensheidsgeskiedenis veral bepaal word deur die bydrae wat dit gelewer het tot, en die invloed wat dit gehad het op die kultuurontwikkeling van die mensheid. Die Westerse beskawing, wat vanaf die sestiende eeu sy invloed ver buite die grense van Europa laat geld het en uiteindelik 'n wêreldbeskawing geword het wat ander beskawings en kulture verdring het, sal sonder twyfel 'n baie belangrike plek in enige behandeling van die wêreldgeskiedenis beklee, hoewel dit nie sonder meer as die 'hoofstroom' van die geskiedenis gesien kan word nie. Die ou kulture van Afrika, waaronder veral die Egiptiese beskawing groot wêreldhistoriese invloed gehad het, en die Islamitiese beskawing, wat deels in NoordAfrika ontwikkel het, behoort byvoorbeeld ook heelwat aandag te ontvang.

\section{Ten slotte}

Ten einde ' $n$ Eurosentriese sowel as ' $n$ Afrosentriese beeld van die Suid-Afrikaanse geskiedenis te vermy, behoort die geskiedenis van Suid-Afrika dus binne die perspektief van die wêreldgeskiedenis behandel te word. Hoewel dit by die skryf van 'n oorsigwerk nie altyd moontlik is om uitgebreid aan te toon hoe ontwikkelinge in Suid-Afrika deel vorm van 'n groter geheel nie, is dit tog noodsaaklik dat werke tot stand kom waarin die breë konteks voldoende aandag kry In sulke werke kan die geskiedenis teen die agtergrond van ontwikkelinge in Afrika behandel word, maar moet ook aangedui word hoedat die geskiedenis van Afrika deel vorm van 'n groter eenheid en hoedat Suid-Afrika, soms saam met die res van Afrika, deur ontwikkelinge in die Westerse wêreld beïnvloed is. Dit is verder wenslik dat die Suid-Afrikaanse geskiedenis in skool- en universiteitsillabusse binne die konteks van die wêreldgeskiedenis behandel word. Die skerp grense wat daar nog meesal tussen Suid-Afrikaanse en 'algemene' geskiedenis bestaan, behoort dus te verdwyn. Indien daar by studente en skoliere 'n goeie kennis en 'n eenheidsbeeld van die wêreldgeskiedenis gevorm en die Suid-Afrikaanse geskiedenis dan binne die kader daarvan behandel word, word dit moontlik om die Suid-Afrikaanse geskiedenis in 'n wyer perspektief te sien en 'n eensydige Westerse of Afrosentriese siening te vermy. Soos hierbo aangetoon, kan en behoort ' $n$ Christelike geskiedbeskouing ' $n$ besondere rol in die vorming van so ' $n$ eenheidsbeeld van die wêreldgeskiedenis, en daardeur ook van die Suid-Afri- 
Van 'n Eurosentriese na 'n Afrosentriese Geskiedenis - is daar 'n altermatief?'

kaanse geskiedenis, te speel. Daar kan in 'n sillabus sekerlik ook plek gemaak word vir die studie van die geskiedenis van 'n besondere gebied, soos byvoorbeeld Afrika suid van die Sahara, Transvaal, of die Vaaldriehoek, mits dit nie so gedoen word dat die geheelbeeld wat van die geskiedenis gevorn word daardeur verwring word nie

Dit bly noodsaaklik dat in die onderrig van Geskiedenis, veral op universiteitsvlak, verskillende interpretasies van besondere historiese gebeure, en ook van die Suid-Afrikaanse geskiedenis as geheel, bespreek word en nie net een interpretasie aangebied word asof dit die enigste moontlike een is nie. As verskillende beskouinge van die geskiedenis egter net naas mekaar gestel word en dit aan studente en skoliere oorgelaat word om 'n keuse te maak, bevorder die vak Geskiedenis verdeeldheid tussen die verskillende samelewingsgroepe in die land. As die vak, daarenteen, aangebied word vanuit 'n lewensbeskoulike grondslag wat ruim genoeg is om politieke en kultuurverskille te oorbrug, en waardeur dit moontlik word om verskillende interpretasies teen mekaar op te weeg en te evalueer, kan dit juis 'n verenigende faktor in die Suid-Afrikaanse samelewing word.

Mense uit verskillende wêrelddele en met wyd uiteenlopende kulture het in SuidAfrika met mekaar in aanraking gekom en saam bygedra tot die vorming van die Suid-Afrikaanse samelewing soos dit tans daar uitsien. Die vroeë geskiedenis van die inwoners van Suid-Afrika vorm deel van die geskiedenis van Afrika sowel as van Asië en Europa. Nie net in die gemeenskaplike deelhê aan die SuidAfrikaanse geskiedenis nie, maar ook in die gemeenskaplike deelhê aan 'n geskiedenis wat veel verder teruggaan as die bekende Suid-Afrikaanse geskiedenis en veel wyer strek as Afrika, ook wyer as Europa, is daar 'n oorkoepelende eenheid, te midde van die verskeidenheid tussen al die mense van Suid-Afrika. Daarom, des te meer, het ons in Suid-Afrika geskiedenissillabusse nodig wat hierdie eenheid na vore bring. Geskiedskrywing en geskiedenisonderrig vanuit 'n Christelike oogpunt bied veral besondere moontlikhede om die eenheid van die geskiedenis tot sy reg te laat kom en 'n perspektief op die Suid-Afrikaanse geskiedenis te bied wat vir die groot meerderheid van Suid-Afrika se mense aanvaarbaar is.

\section{Bibliografie}

ALLARDYCE, G. 1990. Toward World History: American Historians and the Coming of the World History Course. Journal of World History, 1(1):23-76

AMIN, S. 1989. Eurocentrism. London : Zed Books. (Vertaal uit Frans.)

BEBBINGTON, D. 1979. Patterns in History. Leicester : Intervarsity.

BERGH, J.S. 1987. Uitdagings aan die Suid-Afrikaanse historikus. Historia, 32(2):14-26

CAIRNS, G. 1963. Philosophies of History. London : Owen

COLLINGWOOD, R.G. 1946. The Idea of History. Oxford : University Press.

DAVENPORT, T.R.H. 1991. South Africa; a Modern History. London : Macmillan. (Fourth edition.)

DE KLERK, P. 1988. Geskiedenis as kultuurontwikkeling. Pretoria : Serva. 
DE KLERK, P. 1989. Die rol van kolonialisme in historiese ontwikkeling. Koers, 54(3):249271

DE KLERK, P. 1992. Die eenheid van die geskiedenis. Potchefstroom : PU vir CHO. (Wetenskaplike Bydraes, Reeks H: Intreeredes, nr. 128.)

DEN BOER, W., HUGENHOLTZ, F.W.N. \& LOCHER, T.J.G. 1960. Gestalten der geschiedenis in de Oudheid, de Middeleeuwen en de Nieuwe Tijd. Haarlem : Fibula-Van Dishoeck.

DOOYEWEERD, H. 1955. A New Critique of Theoretical Thought, vol. 2. Amsterdam Paris.

DREYER, P.S. 1974. Inleiding tot die filosofie van die geskiedenis. Kaapstad : HAUM.

ELPHICK, R. \& GILIOMEE, H. 1989. The Shaping of South African Society, 1652-1840 Cape Town : Maskew Miller Longman. (Second edition.)

FISCH, J. 1990. Geschichte Südafrikas. München : Deutscher Taschenbuch Verlag.

GARSON, N.G. 1992. Rodney Davenport and Contemporary History. Suid-Afrikaanse Historiese Joernaal, 26:53-56

GREEN, W.A. 1992. Periodization in European and World History. Journal of World History, 3(1): 13-54.

HARMSEN, G. 1968. Inleiding tot de geschiedenis. Baarn : Ambo

HITCHENS, M.J. 1990. World History Textbooks for High Schools: a Review. World History Bulletin, 7 (2):8-15.

KAPP, P.H. 1992. Doelstellings, doelwitte en kriteria Gister en Vandag, 24:3-10.

KLAPWIJK, J. 1974. Geloof en geschiedenis. (In Popma, K.J. et al. Het leven beschouwd. Amsterdam : Buijten \& Schipperheijn. p. 53-80.)

KULKE, A. \& ROTHERMUND, D. 1986. A History of India. London : Routledge

KUYPER, A.A. 1959. Het Calvinisme; zes Stone-lezingen. Kampen: Kok. (Derde druk.)

LE CORDEUR, B. 1992. What is South African History? Suid-Afrikaanse Historiese Joernaal, 26:39-43.

LEDBETTER, R. 1992. Some Thoughts on the Historiography of World History. World History Bulletin, 9(2):12-17.

LEGASSICK, M. 1992. Awaiting a Revisionist Synthesis. Swid-Afrikaanse Historiese Joernaal, 26:44-49.

LEVINE, M.M. 1992. The Use and Abuse of Black Athena. The American Historical Review, 97(2):440-460.

LIEBENBERG, B.J. 1990. Resensie van H.J. van Aswegen, Geskiedenis van Suid-Afrika tot 1854. Suid-Afrikaanse Historiese Joernaal, 22:214-216.

MANNING, P. 1992. Methodology and World History in a Ph.D.-Program. Perspectives, 30 (4):22-27.

MARTEL, E. 1991-1992. Afrocentric Historical Claims: an Examination of the Portland, Oregon, African-American Baseline Essays. World History Bulletin, 8 (2):13-16.

McINTIRE, C.T. 1975. The Ongoing Task of Christian Historiography. (In Marsden G. \& Roberts F. eds. A Christian View of History? Grand Rapids : Eerdmans. p. 51-74.)

McINTIRE, C.T. ed. 1977. God, History and Historians. An Anthology of Modern Christian Views of History. New York : University Press.

McINTIRE, C.T. 1984. Historical Study and the Historical Dimension of Our World. (In McIntire, C.T. \& Wells, R.A. eds., History and Historical Understanding. Grand Rapids : Eerdmans. p. 17-40.)

McNEILL, W.H. 1963. The Rise of the West: A History of the Human Community. Chicago : University Press.

McNEILL, W.H. 1990. The Rise of the West after Twenty-five Years. Journal of World History, 1(1):1-21 
Van 'n Eurosentriese na 'n Afrosentriese Geskiedenis - is daar 'n alternatief?

MESSINA, E. 1991. Resensie van H. Giliomee en R. Elphick, reds., in Samelewing in wording. Suid-Afrikaanse Historiese Joernaal, 25:291-293

MULLER, C.F.J. red. 1980. Vyfhonderd jaar Suid-Afrikaanse geskiedenis. Pretoria : Academica. (Derde uitgawe.)

RAVITCH, D. 1991. History and the Perils of Pride. Perspectives, 29 (3):12-13.

ROSS, R. 1989. The Cape of Good Hope and the World Economy, 1652-1835. (In Elphick R. \& Giliomee H eds. The Shaping of South African Society, 1652-1840. Cape Town : Maskew Miller Longman. p. 243-282.)

SCHUTTE, G.J. 1989. Company and Colonists at the Cape, 1652-1795. (In Elphick R. \& Giliomee H. eds., The Shaping of South African Society, 1652-1840. Cape Town : Maskew Miller Longman. p. 283-323.)

SINGER, A. 1990. Multicultural Education is Good Education - But it Can't Perform Miracles. Perspectives, 28(9): 14-16

SMIT, M.C. 1950. De verhouding van Christendom en historie in de huidige RoomsKatholieke geschiedbeschouwing. Kampen : Kok

SMIT, M.C. 1987. De eerste en tweede geschiedenis. Amsterdam : Buijten \& Schipperheijn.

SMITH, I.R. 1992. The Most Useful Book on South Africa's Past. Suid-Afrikaanse Historiese Joernaal, 26:49-52.

STAVRIANOS, L.S. 1971. Man's Past and Present; a Global History. Englewood Cliffs (N.J.) : Prentice-Hall.

STEARNS, P.N. 1989. Teaching the United States in World History. Perspectives, 27(4): 12-16.

THAPAR, R. \& SPEAR, P. 1965-1966. A History of India. Harmondsworth : Penguin (2 vols.)

THOMPSON, L.M. 1990. A History of South Africa. New Haven : Yale

TOYNBEE, A.J. 1935-1961. A Study of History. Oxford : University Press (12 vols.)

UNESCO. 1963-1966. History of Mankind; Cultural and Scientific Development. London Allen \& Unwin (6 vols.)

VAN ASWEGEN, H.J. 1989. Geskiedenis van Suid-Afrika tot 1854. Pretoria : Academica

VAN DER DUSSEN, W.J. 1986. Filosofie van de geschiedenis; een inleiding. Muiderberg Coutinho.

VAN DER MERWE, B. de V. 1967. Christelik-reformatoriese geskiedbeskouinge. Bloemfontein : UOVS. (M.A.-verhandeling.)

VAN DER WALT, B.J. 1978. Horizon; Surveying a Route for Contemporary Christian Thought. Potchefstroom : PU vir CHO (IRS)

VAN JAARSVELD, F.A. 1980. Westerse historiografie en geskiedenisfilosofie. Pretoria HAUM.

VAN JAARSVELD, F.A. 1982. Van Van Riebeeck tot P.W. Botha. Johannesburg : Perskor. (Derde uitgawe.)

VAN JAARSVELD, F.A. 1989. Omstrede Suid-Afrikaanse skoolgeskiedenis. His/oria, 34 (2): $1-21$

VOGT, J. 1961. Wege zum historischen Universum. Stuttgart : Kohlhammer.

WALLERSTEIN, I. 1974-1989. The Modern World-System. New York : Academic Books (3 vols.)

WHEATCROFT, G. 1992. Veldt Ironies. History Today, 42:57-58.

WILSON, M. \& THOMPSON, L.M. eds. 1969-1971. The Oxford History of South Africa Oxford : Clarendon (2 vois.) 